\title{
Hiring of Flexible and Fixed-term Workers in Five Norwegian and Swedish Industries'
}

\author{
I Jørgen Svalund ${ }^{2}$ \\ Researcher, Fafo, Norway
}

\section{Anna Peixoto}

Senior lecturer, University of Gothenburg, the department of Sociology and Work Science, Sweden

\section{Jon Erik Dølvik}

Senior researcher, Fafo, Norway

\section{Kristin Jesnes}

Researcher, Fafo, Norway

\begin{abstract}
Analyzing how and why employers use fixed-term contracts or alternative forms of flexible, shortterm labor in five labor-intensive industries in Nonway and Sweden, the main research question in this article is how employer hiring of temporary labor is affected by differences in national employment regulations and industries. Regarding employer motives, we find strong and similar inter-industry differences across the two countries, while the share of fixed-term employees is generally higher in Sweden than in Norway where regulations are stricter. Further, employers' hiring of fixed-term labor is contingent on their access to alternative sources of flexible labor when faced with shifting demand, need for substitutes, or complex shift plans. The mix of fixed-term labor, agency workers, and use of extra part-time work also varies across industries, depending on the pattern of production, work organization, and workforce gender profile.
\end{abstract}

\section{KEYWORDS}

Agency work / employers / employment protection regulation / fixed-term employment / flexibility

\section{Introduction}

ince the 1980s, the rise of flexible temporary and non-standards forms of work has featured centrally in the literature (Atkinson 1984; OECD 1994; Pollert 1988).

Especially after the recent financial crisis, rising insecurity and precariousness has spurred renewed attention to theories linking various non-standard contracts to segmentation or dualization of labor markets (Doeringer \& Piore 1971; Emmenegger, Häusermann, Palier \& Seeleib-Kaiser 2012; Gallie 2007; Rueda 2006). A central question in this literature is how and why the prevalence of temporary contracts varies

\footnotetext{
${ }^{1}$ You can find this text and its DOI at https://tidsskrift.dk/njwls/index.

${ }^{2}$ Corresponding author: Jørgen Svalund, Fafo, PB 2947 Tøyen, 0608 Oslo, Norway.

E-mail: jorgen.svalund@fafo.no.
} 
between institutional settings and countries belonging to different employment regimes (Gallie 2007). While much research has studied the impact of non-standard work on employees' job careers, the focus in this article is on why employers hire labor on fixedterm contracts and how that is influenced by the availability of other forms of temporary labor. How do employers' flexible hiring practices vary across industries, and how are such practices influenced by differences in the regulation of temporary contracts in the otherwise similar Swedish and Norwegian employment regimes? Applying a most similar method of comparison and building on interviews with company/site management in the automotive industry, food industry, warehouses, retail, and care services, we examine employer reasons and justifications for hiring temporary workers ${ }^{1}$ at 34 labor-intensive workplaces with modest skill requirements in Norway and Sweden. While existing literature has often focused on differences in hiring practices between continental, liberal, and Nordic labor markets, interpretations vary regarding the latter: Some authors suggest that the inclusive Nordic employment regimes are least prone to dualization (Gallie 2007), whereas others suggest that the strong Nordic employment protection and (insider) labor organizations tend to spur as much dualization as in the continental countries (Lindvall \& Rueda 2014). In this view, we argue that a comparison of companies' use of temporary workers in different industries in Sweden and Norway - where temporary work is very differently regulated - is pertinent, and that our study of such 'within-type' variation adds importantly to the existing literature.

While the effects of fixed-term and temporary contracts on employee careers are studied at length through quantitative analysis, there is limited knowledge about employers' choices, preferences, and motivations for using such contracts. According to Atkinson (1984) and Houseman (2001), employers use temporary contracts to enhance numerical workforce flexibility, especially when hiring employees for jobs requiring limited qualifications and company specific training. While national regulation may create barriers to employer use of temporary workers, employers have limited incentives for using such contracts in contexts with lax dismissal regulation of permanent contracts (Polavieja 2003). The marked differences in Swedish and Norwegian dismissal protection for permanent labor, and in the regulation of fixed-term employees (FTE) and temporary agency workers (TAW) may thus engender differences in how and why Swedish and Norwegian employers use such contracts.

Given the high dismissal costs flowing from strict regulation of permanent contracts, Blanchard and Landier (2002) suggest that employers often use temporary contracts to screen potential employees, especially applicants who have limited work experience, formal skills, or may otherwise pose a risk. Through temporary work employers can screen unmeasurable aspects of potential recruits' abilities, for example, their motivation or special competences (Houseman 2001; Korpi \& Levin 2001).

The few studies of employers reasons for using fixed-term contracts are rather old and mostly from the US (Davis-Blake \& Uzzi 1993; Houseman 2001; Kalleberg, Reynolds \& Marsden 2003), with two Nordic exceptions using data from 1996 and 1997 (Nesheim 2003; Olsen \& Kalleberg 2004). Besides stronger dismissal protection, and high unionization and collective agreement coverage, the extensive rights to leave of absence in Norway and Sweden may increase employers' need for supply of temporary substitutes (Olsen \& Kalleberg 2004). Further, while use of fixed-term contracts, contrary to in the US and UK, is relatively well defined in Norwegian and Swedish law (Nesheim 2002), the rules are much laxer in Sweden - also regarding the use of agency




workers (Alsos \& Evans forthcoming). Thus, our comparative design aims to discern the effects of significant differences in the regulation of these specific forms of non-standard employment, in these otherwise similar Nordic countries.

In recent employment relations literature, the focus on national regulatory systems have increasingly been supplemented by attention to the impact of industry-specific traits and similarities across countries (Bechter, Brandl \& Meardi 2012; Marginson, Arrowsmith \& Sisson 2004:20). Producing specific goods or services, companies in different industries marked by different technologies, skills, and needs for labor, seek to structure their workforce in ways optimizing efficiency and timing of production (Scott 2003: Chapter 2). Employers' choice of employment contracts are also likely to be conditioned by industry differences, fluctuations of market demand, and supply of relevant labor (Bechter et al. 2012). Further, it is important to keep in mind that in certain industries, employers demand for temporary workers emerge from their need to maintain stable services $24 / 7$ and secure stability in shift-plans by means of short-term labor. A typical example is public care services. Alternative sources to maintain stable services are TAWs or part-timers working extra hours (Håkansson \& Isidorsson 2016; Kalleberg et al. 2003; Olsen \& Kalleberg 2004). In this view, our second main research question is whether the use of fixed-term contracts and TAWs in different industries varies in similar ways in countries with different regulations. In this way, we aim to examine the impact of industry, and how the interplay between industry characteristics and national regulations affects employer hiring practices.

For employers in need of staff flexibility, FTE, TAWs, and part-timers working extra hours may serve as functional equivalents. Still, most studies of employers' use of temporary workers focus solely on one form of temporary work, often fixed-term contracts, and ignore how the use of such contracts is influenced by the availability of alternative forms of non-standard contracts. The few studies analyzing all of these flexibility arrangements simultaneously are quantitative, and focus only on structural differences between companies using several types of flexible labor by way of correlations, not by studying the motivations for and ways of combining different non-standard contracts (Kalleberg et al. 2003; Olsen \& Kalleberg 2004). Hence, previous research provides limited understanding of the mechanisms and regulative differences influencing employers' choice of contracts in different contexts. A third research question aimed to shed light on when and why employers prefer fixed-term hiring is therefore how their use of such contracts is influenced by the legal and practical availability of TAWs or part-timers working extra hours, and vice versa.

Exploring these issues, the article first discusses analytical perspectives and prior research, before presenting the research design and methods used. On the basis of the interviews, we then give a descriptive overview of Swedish and Norwegian employers' staffing practices across industries, before analyzing why employers staff the way they do. Finally, the results are discussed and the article concluded.

\section{Employers' use of temporary contracts: Analytical perspectives and previous research}

When analyzing the impact of differences in national regulations on employers' motives, practices, and choices regarding temporary staffing, and how employer practices vary 
between companies in different industries across the two countries, there are different analytical approaches that can be applied. Here, we first refer the conventional approaches to staffing flexibility emerging from labor economics, and then refer to institutionalist perspectives on how regulative and normative differences can affect employers' hiring strategies.

\section{Flexibility vs. stability}

In labor economics, fluctuations in demand and production are the prime reason for employers' use of fixed-term and agency workers (Coe, Johns \& Ward 2009; Houseman 2001; Morikawa 2010). Further, employers' perceived need for temporary labor varies with the easiness with which they can adjust the workforce in times of shrinking production, that is, the strictness of dismissal rules for permanent employees.

Atkinson's (1984) model of the flexible firm is a typical reference in analyses of how and why employers rely on different contracts and sources of labor. As companies combine functional and numerical flexibility to adjust the workforce size and skills to fluctuating production, Atkinson expects companies to develop distinct segments of core and peripheral workers. The permanent core workers characterized by advanced, multiple skills provide functional flexibility, while peripheral workers mostly performing routine work hired on various temporary and short-term term contracts offer numerical flexibility in case of sudden demand or activity shifts. Part-time and on-call labor, whether on open-ended or fixed-term contracts, required to work variable hours provide additional sources of numerical flexibility.

Flexible adjustment to demand fluctuations or changes in production technology is as mentioned not the only reason for employers' use of temporary workers. Several studies show that employers may also prefer loose ties with parts of the workforce to maintain numerical stability (Håkansson, Isidorsson \& Kantelius 2013; Nesheim 2003:328). For instance, employers in care services are obliged to provide stable services to a set number of residents, but the need for labor varies in predictable ways during the workday and work-week. As stability in services entails complex shift-plans, varying needs for labor and skills require supply of flexible extra staff in the form of part-timers, oncall or temporary labor that can fill in vacant shifts, substitute for people on leave, or buffer predictable fluctuations in the supply of labor.

\section{Reactive vs. strategic/proactive use of temporary workers}

Use of temporary workers may both arise as ad-hoc reactions to demand or workforce fluctuations or in a more planned, strategic manner (Holst, Nachtwey \& Dörre 2010; Vidal \& Tigges 2009). Studying manufacturing companies' hiring of temporary workers in Wisconsin, Vidal and Tigges (2009:56) point out three ways such workers can be used to boost numerical flexibility. Besides reactive dealing with unexpected demand fluctuations, they can be used in a strategic manner to accommodate predictable activity variations as when employers deliberately keep a permanent staff that is unable to cover for peak months to avoid slack. Finally, they can be used systematically in longer-term strategies where only core tasks are performed by permanent staff, while specific, less skill-demanding job categories are lastingly filled with temporary workers. 


\section{Regulative, normative, and cognitive institutional pillars}

When analyzing how legislative differences affect the employers' use of temporary labor in Norway and Sweden, it is important to take into account that employer judgments regarding staffing policies are framed and filtered by institutions based on regulative, normative, and cognitive pillars structuring their choices (Scott 2008:48). Among these pillars, only the regulative pillars are mandatory and can be sanctioned by a third party (Mahoney \& Thelen 2010).

Sociological theories highlight that employers have an interest in decreasing uncertainty or increasing legitimacy (DiMaggio \& Powell 1991). Regulative pillars influence employers' hiring decisions by affecting their considerations of efficiency, costs, and legitimacy. As FTEs and TAWs may be perceived as functional equivalents, it is ceteris paribus likely that the stricter the rules for use of TAWs, the higher use of fixed-term contracts, and vice versa (Nesheim 2004:16). Vosko (2010) points out that the understanding of permanent and temporary contracts is centered around social norms related to the 'standard employment relationship' (SER) - the permanently employed full-time worker - on the one hand, and laws and regulations on the other. When not using the SER, employers may justify their 'non-standard' choice not only by what is legally allowed but also by employees' and the community's expectations of the employer, perceived understandings of fairness, legitimacy, and other considerations that go beyond prescriptive rules in legislation or collective agreements (March \& Olsen 1984). The use of FTE and TAW is to some extent institutionalized in the Swedish and Norwegian labor markets, even though the specific regulations have changed in recent decades - especially in Sweden (Håkansson \& Isidorsson 2007; Nergaard 2016).

Pointing toward the significance of cognitive institutional pillars, Scott (2008:35) stresses that actors such as employers tend to follow - comply with - certain behaviors within an organizational field (DiMaggio \& Powell 1991). Their compliance might be based on culturally supported, taken for granted, mimetic behaviors. Employer practices are thus not only influenced by regulative or normative rules but also by how the individual employer cognitively understands the social world and the industry (field) their company belongs to. In this perspective, perceptions of legitimacy and how other companies structure production and abide by rules and regulations are important for how a particular employer understands their position and latitude for choice.

\section{Former studies}

There is limited research of employers' motivations, perceptions, and use of non-standard workers from Norway, Sweden, or other Nordic countries, while there are a few studies from the US and Britain in the 1990s (Houseman 2001; Kalleberg et al. 2003; Uzzi \& Barsness 1998). Comparing employers in Norway and the US in 1996-1997, Olsen and Kalleberg (2004) examined their use of non-standard labor, including FTEs, TAWs, and contractors. They found that the Norwegian companies made greater use of nonstandard work arrangements partly due to more restrictive employment protection legislation (EPL) for permanent workers, and partly due to the generous access to leave of absence in Norway. In a study of Norwegian companies' use of fixed-term contracts and TAWs in 1996 (Nesheim 2003:321) found that the employers simultaneously listed 
a range of reasons (substitutions, seasonal shifts, variations in workload, need for special competence, screening) for their use of temporary workers. The most common reason was substitutions and seasonal shifts. Studying employer use of TAWs in Sweden in 2012, Håkansson and Isidorsson (2016:60-61) find that two-thirds of the employers say they use TAWs for flexibility reasons, $58 \%$ for stability reasons, and $19 \%$ as a buffer, while $10 \%$ cited recruitment difficulties. Using TAWs as a buffer was most common in manufacturing. Olsen and Kalleberg (2004) found that both in the US and Norway, public sector employers were more likely to hire fixed-term workers and less inclined to use TAWs than private firms, partly due to the higher share of female-dominated occupations in public services, and gendered family-work life balance preferences. In this respect, industry differences between public and private companies seemed more important than the large differences in national regulations. Studying correlates between different flexible staffing arrangements among US companies, Kalleberg et al. (2003) found that many employers supplemented open-ended, full-time contracts with combinations of part-time, fixed-term, and sometimes TAW contracts (Kalleberg et al. 2003:539-540). In either of these studies were the employers asked why they chose the specific combination of contracts they did, and the possibilities to explain the variations in such use were thus limited.

Finally, cyclical shifts in aggregate labor demand and supply is an often neglected factor in explaining variations in employer use of non-standard contracts. In times of sluggish growth, employers may be reluctant to hire new permanent staff and prefer temporary hiring to reduce uncertainty. Conversely, in contexts of labor shortages, employers may use temporary work agencies simply to get hold of employees. Hence, Kalleberg et al. (2003) found that perceived labor shortage in the US was positively related to the hiring of fixed-term and part-time workers, often in shorter contracts filled by individuals without the desired education or skills. Illustrating the impact of supply constraints, Houseman (2001) found that 54\% of US employers used part-time contracts because of demand from the employees: a high share of female workers wanted part-time to balance work and family obligations - a phenomenon that is familiar in Norway and Sweden as well.

\section{Methods and comparative design}

To disentangle the impact of differences in national regulation of temporary work and industry variations in companies' market positions and mode of production across countries, we apply a 'most similar' comparative design (Ragin 198748 ). As parts of the Nordic family of models, Sweden and Norway are very similar except when it comes to the regulation regarding fixed-term work, TAWs, and dismissal protection for permanent staff, which are under scrutiny in this study. Below, we outline the main differences in regulation and prevalence of temporary work, and then account for the selection of cases and methods used in data gathering.

\section{Differences in the Norwegian and Swedish regulative context}

Employers' interest in fixed-term contracts depends partly on the strictness of dismissal regulation. The regulation of individual and collective dismissals is according to the 
OECD EPL index for 2013, ranging from 0 to 6, somewhat stricter in Sweden (2.52) than in Norway (2.31). The actual rules and practices differ somewhat. In Norway, the Working Environment Act and the Civil Servants Act do not specify any criteria guiding the selection of whom to dismiss in a downsizing-process, but the Basic Agreement between the main social partners' states that seniority should be applied. This principle may be deviated in situations where there is due reason (chapter 10, $\$ 9.12$ ). In Sweden, by contrast, the last-in-first-out principle is mandatory in the Law on Employment Protection (LAS 1982:80) - with the prerequisite that the remaining employees have qualifications to carry out the work. A comparison of downsizing in manufacturing companies in Norway and Sweden indicates that the seniority rules are implemented more flexibly in Norway, requiring less procedural effort and leaving more room for employer choice regarding dismissal selection (Svalund, Casinowsky, Dølvik, Håkansson, Jarvensivu, Kervinen, Møberg \& Piirainen 2013). Hence, employers may have stronger reasons to use temporary employees rather than permanent employees in Sweden.

According to OECD's EPL-index from 2013, Sweden has one of the most liberal regulations of fixed-term contracts $(0.75)$, while Norway had one of the strictest regulations (3.50) in the OECD area, ${ }^{2}$ which changed somewhat during 2015, after our interviews. In Norway, fixed-term contracts (and TAWs) could during the period of our study only be used to substitute workers temporarily or when the work differed from work ordinarily performed in the company. The rules are largely similar in Sweden, but with one major exception. The employers do not need to specify why they use a so-called 'general fixed-term' contract.

As an alternative to fixed-term contracts, employers may use TAWs for flexibility and screening purposes. According to the OECD EPL-index from 2013, Sweden had among the most liberal regulations of temporary agency work (1.58), while Norway were comparatively stricter (3.33) (OECD 2013:90). ${ }^{3}$ In Sweden, there is no specific regulation pertaining to temporary work agencies. They are treated like any other business, and there are no restrictions on employers' hiring of labor from them (Håkansson \& Isidorsson 2012). In Norway, the conditions for using agency workers have been the same as for fixed-term contracts, but the new option to use general fixed-term contracts up to 1 year from July 1, 2015 (after this study was conducted) does not apply to agency workers.

\section{Differences in the overall use of non-standard employment}

About $17 \%$ of all employees in Sweden were fixed-term employed in 2014, compared with $8 \%$ in Norway (Table 1 ). There are rather large national differences in the use of FTEs within the industries studied in this article: $6 \%$ of those working in wholesale and retail are fixed-term employed in Norway, compared to $15 \%$ in Sweden. The shares are also much higher in transportation and warehouses, and in human health and social work activities (which include care services) in Sweden than in Norway. The exception is manufacturing were there are only modest national differences.

In 2014, about 58,700 employees worked for temporary work agencies in Norway (Nergaard 2016:50), compared with 81,300 in Sweden (Statistics Sweden 2016:15), representing between $1.5-2 \%$ and $1.5 \%$ of all employees, respectively (Håkansson \& Isidorsson 2016:48; Nergaard 2016:55). A large share of the agency workers in Norway 
Table I Fixed-term employment

\begin{tabular}{lcc}
\hline & Norway & Sweden \\
\hline Total & 8 & 17 \\
C. Manufacturing (including food industry) & 5 & 7 \\
G. Wholesale and retail & 6 & 15 \\
H.Transportation and warehouse & 5 & 13 \\
Q. Human health and social work activities & 11 & 19 \\
\hline
\end{tabular}

Percentage of all employed. 2014. Nace. 15-64 years of age.

Source: (Eurostat 20 I 6b).

is employed within construction and shipyards. In Sweden, the collective agreement in construction prohibits agency workers and the main user industry is manufacturing (Alsos \& Evans forthcoming).

Finally, part-time workers may provide employers extra man-hours when needed. While part-time employment can be involuntary, it is rather normalized in both countries. In 2014, 26\% of the labor force in Norway had a part-time job, and $25 \%$ in Sweden (Eurostat 2016a). In general, the percentage of employees working part-time is in both countries high in female-dominated industries such as care services, while it is low in male-dominated industries such as manufacturing, in both countries.

\section{Methods and company selection}

To understand how and why employers use temporary workers, and how and why different types of labor are combined in distinct ways, a case study approach is useful (George \& Bennett 2005). The choice of industries and workplaces was based on variation in 1) skill levels and needs, 2) demand volatility and need for staff stability, 3) hiring of TAWs, and 4) in producing goods or services, as well as a gender mix. Six manufacturing plants, five food industry plants, eight large service industry warehouses, six large retail companies, and nine care service organizations were selected. The size of the workplaces varied within each industry. We have conducted interviews with managers in 34 workplaces, carried out from October 2014 to May 2015, in Norway and Sweden.

The selected manufacturing plants were either operating as end-producers or subcontractors characterized by Just-In-Time mass production, had a sizable amount of international exports, and experienced rapid shifts in demand. In contrast, the selected firms in the food industry mainly produce food for distribution to stores nationally and face fierce competition and huge seasonal shifts in demand. In both manufacturing and food industry, the skill level in each company varied from very skilled jobs to lower skilled jobs. To study an industry requiring mainly low-skilled workers, we selected warehouse companies distributing furniture, food, clothing, etc. to stores and consumers in the Nordic markets. Most of them had to cope with large fluctuations. Only specific positions such as drivers required specific formal skills. Further, we selected retail companies that sell clothes and accessories marked by close interaction with the customers. These faced shifts in daily, weekly, and seasonal demand, and were dominated by female 
labor. Most of the work could be described as low-skilled, where knowledge about products and fashion is developed over time. We also selected nine care service workplaces, which had both day and night shifts, except one providing recreational activities during afternoons and weekends to disabled people. The need for stability in staffing was high, as there were minimum requirements regarding the number of nurses and other types of personnel present. The skill requirements were relatively high in most positions except for the company providing service to the disabled.

The manufacturing, warehouse, and food industry are male dominated, while retail and care services are female dominated.

\section{Interviews}

Several of the companies were part of larger organizations. Our cases comprised the activities conducted at site. Data were collected through interviews and supplemented with publicly available information about the case unit. All in all, 38 representatives of management were interviewed, some multiple times whenever more information was needed. The interviews took approximately 1 hour, and were recorded and transcribed in full. The interviews were conducted face-to-face, except one that was conducted by phone. Some complementary information was sent by e-mail. We interviewed the representative of site management who was in charge of recruitment and staffing, to get first-hand information on employer practices regarding hiring and staffing. The interviews were semi-structured, aiming for comparable information about processes and choices ('truth seeking'), more than subjective meanings (Cho \& Trent 2006:326). Still, we wanted the interviewees to tell their story, ensuring that the informants provided relevant information. By asking concrete questions about real hiring situations, and what happened to those hired as TAWs and FTEs, we tried to capture what really happens in such situations at the different workplaces. Further, we asked specifically about the use of different types of contracts, why they were applied, and whether the employees still worked in the company, also providing insight into employer staffing practices rather than general opinions about temporary work and regulation. Focusing on practices and the specific reasoning behind concrete personnel choices, the interviews gave rich insight into employers' assessments of the pros and cons of different employment contracts and the rules pertaining to them.

\section{Analysis}

Doing the analysis, there was a continuous iterative movement between questions, data concepts, and (possible) answers. In both countries, we first analyzed each case and its internal dynamics concerning use of temporary workers, then we compared differences and similarities between single cases, within and between industries and countries as a whole. During this iterative process, new concepts and understandings emerged, especially related to how the gendered use of the SER influenced employer possibilities and practices, as well as how similar justifications for hiring temporary workers within companies in Norway and Sweden were used to stress why their company 'had to' use temporary workers, and how such justifications interacted with differences in regulations. 


\section{Variation in employers' staffing practices across industries - a descriptive overview}

All companies in both countries stated that they based their staffing primarily on permanent employees, but just a few relied almost entirely on full-time permanent employees (SER). The companies showed distinctly different industry profiles, using different combinations of types of contracts to secure stability and flexibility attuned to the companies' need for labor and skills during the day, week, and season (Table 2).

In the Norwegian manufacturing companies, FTEs - including a few on-call workers - or TAWs were used on a limited scale, mainly ad-hoc to increase numeric flexibility during temporary demand increases, vacations, or longer sick leaves. These temporary workers were mostly assigned tasks requiring modest competence. $\mathrm{NM}^{4}$ was exposed to large seasonal shifts in demand, and during periods of high activity, overtime work was combined with functional flexibility in the staff, while the large stock of products were reduced. Permanent employees were also predominant in the Swedish manufacturing companies, but they used to a larger extent TAWs, combined with FTEs. The Swedish companies used temporary contracts strategically as a buffer even when knowing the need for labor was permanent, and as entrance ports for recruitment.

The food industry companies in both countries made products requiring lower skills, and based their staffing mostly on permanent employees. As in manufacturing,

Table 2 Organizational staffing profiles in the five industries in Norway and Sweden

\begin{tabular}{|c|c|c|}
\hline Industry & Norway & Sweden \\
\hline I. Manufacturing & $\begin{array}{l}\text { Predominantly SER, combined with use } \\
\text { of FTE ad-hoc, and during short-term } \\
\text { demand shifts }\end{array}$ & $\begin{array}{l}\text { Medium level of SER combined with a } \\
\text { high share of TAWs and a share of FTE }\end{array}$ \\
\hline 2. Food industry & $\begin{array}{l}\text { SER, combined with limited use of FTE } \\
\text { ad-hoc, and during short-term demand } \\
\text { shifts }\end{array}$ & $\begin{array}{l}\text { SER, limited use of FTE ad-hoc, and dur- } \\
\text { ing short-term demand shifts. SFI also } \\
\text { used TAWs during seasonal shifts. }\end{array}$ \\
\hline 3. Warehouses & $\begin{array}{l}\text { Medium to high level of SER, combined } \\
\text { with strategic, large-scale, or ad-hoc use } \\
\text { ofTAWs during short-term demand } \\
\text { shifts, sick leave etc., and a few FTE on } \\
\text { medium-term contracts. }\end{array}$ & $\begin{array}{l}\text { Medium to high level of SER, combined } \\
\text { with strategic large-scale use of FTE and } \\
\text { TAWs during short-term demand shifts, } \\
\text { sick leave etc. }\end{array}$ \\
\hline 4. Care services & $\begin{array}{l}\text { A few SER, a high level of permanent } \\
\text { part-time employees, combined with } \\
\text { on-call and part-time workers putting in } \\
\text { extra hours, and occasionally assistants } \\
\text { on FTE. }\end{array}$ & $\begin{array}{l}\text { A few SER, a medium level of permanent } \\
\text { part-time employees, combined with } \\
\text { high use of assistants on fixed-term, } \\
\text { on-call, and part-time contract putting in } \\
\text { extra hours. }\end{array}$ \\
\hline 5. Retail & $\begin{array}{l}\text { A few SER, a high level of permanent } \\
\text { part-time employees, combined with } \\
\text { on-call workers and part-time putting } \\
\text { in extra hours. No temporary workers } \\
\text { except ad-hoc due to sick leave. }\end{array}$ & $\begin{array}{l}\text { A few SER, a medium level of permanent } \\
\text { part-time employees, combined with a } \\
\text { high use of FTE due to numerical shifts, } \\
\text { combined with on-call and part-time } \\
\text { contracts putting in extra hours. }\end{array}$ \\
\hline
\end{tabular}

Note: High $=$ above $15 \%$, medium $=$ between $7 \%$ and $15 \%$, low $=$ below $7 \%$ of the staff. 
the employers handled short-term absence partly by functional flexibility - reorganizing personnel - partly by using on-call workers, students, and others to do vacant simple jobs because of someone's absence or seasonal shifts. In case of long-term absence, like parental leave, they hired FTEs. Compared to the manufacturing companies, especially in Sweden, the use of temporary employees for numerical flexibility was much lower. None of the companies used FTEs or TAWs to handle sudden shifts, which they did not face often.

In the warehouse companies in both countries, the competence requirements for most jobs were rather low and it was easy to find suitable new personnel. The warehouse companies all had a medium-large proportion of permanent employees, combined with a rather high share of TAWs and a lower share of FTEs. The number of permanent employees was attuned to handle months with low demand, thus TAWs, and in Sweden also FTEs, were used strategically to handle seasonal peaks. In two of the Norwegian companies, TAWs were used mostly reactively, -ad-hoc-, when the employers faced seasonal shifts or sick-leave etc. The last Norwegian company, and two of the Swedish companies, hired TAWs strategically on a larger scale, mostly on short-term. When recruiting new employees, all these companies hired TAWs on short-term contracts, and when they had a more medium-term temporary need (more than 3 months) due to sick leave etc. they hired by way of a fixed-term contract from the pool of TAWs. In case of a permanent need, they hired mostly from the pool of FTEs. Thus, these companies had a rather elaborate, multilayered internal labor market.

The staffing profiles at the care service worksites in these countries showed significant similarities. The workplaces were mainly staffed by permanent employees on large and medium-sized part-time contracts. In view of having a stable number of workers during the day and night, and throughout the week, the care service worksites combined the use of on-call workers with offer part-time workers to work longer hours than stated in their contract. When management sometimes was unable to get hold of trained nurses, they hired unskilled assistants on fixed-term contracts while continuing to search for nurses for permanent contracts. The share of FTEs was higher in the Swedish care institutions than in the Norwegian.

The retail companies in both countries did primarily rely on permanent contracts, but most of these were part-time. Only a few sales persons, managers, and those handling purchasing had full-time, permanent contracts. Some of the open-ended, part-time contracts were small, ranging from zero-hour contracts to around 1 day per week. Stable organization of the work during the day/week was at these worksites contingent on part-timers working more hours, and their strategic use of working-time flexibility served short-term flexibility needs. Still, while the Norwegian retail companies did not use FTEs, except reactively because of long-term sick leave etc., the Swedish companies used a much higher share of FTEs strategically during demand peaks.

\section{Why do the companies use the staffing strategies they do?}

The use of non-standard employees - fixed-term and agency workers, on-call, and parttime workers - varies rather strongly not only between workplaces in different industries but also between the two case countries. While the descriptive overview shows clear 
similarities in staffing patterns within industries across borders, the share of temporary workers was generally higher in several of the Swedish industries than the Norwegian. Part-time workers putting in extra hours and on-call workers filling in gaps in the schedule is a common source of flexibility and stability in the female-dominated care services and retail. The use of SER was much more common in the male-dominated industries, where working-hours provide little flexibility. Instead, FTE and TAW were used to adjust staffing within manufacturing, warehouses, and, when needed, in the food industry.

\section{The impact of national regulative and institutional differences on firm staffing practices}

Despite clear industry profiles regarding use of temporary labor, Table 2 summarizes marked differences between Norway and Sweden as to the levels of temporary workers and use of certain combinations of flexible workers. In this section, we discuss whether and how differences between Norway and Sweden can be accounted for by differences in national regulation. Particularly, did the interviews indicate national differences in the employers' cognitive perceptions, normative understandings, and patterns of recruitment regarding use of temporary, non-standard labor? How did the national regulative, normative, or cognitive institutional pillars interact with industry differences in influencing employers use of temporary workers and extra hours provided by part-time workers across the two countries? As the regulation of fixed-term contracts and TAWs is laxer in Sweden, Swedish employers have more possibilities to hire temporary workers for screening.

The interviews show that even though the regulations regarding use of fixed-term workers were considered rather clear in both countries, managers in Norway often did not know the letter of the law. Instead, they had received guidelines and scripts from the company headquarter, from their HR-predecessor, or had a rather taken-for granted understanding of the regulations and how such contracts had been and should be handled in their company. Thus, the cognitive institutional pillar influenced how the employers applied the regulations, apparently in a more 'flexible' direction.

In both countries, managers expressed that permanent contracts were the norm according to which labor relations were and should be handled within the company. When asked if the last recruit was hired on a temporary or permanent contract, one employer in health care answered as follows:

We do not hire on temporary contracts. No, we only have permanent contracts, except some weekend-agreements.

When the managers talked about their temporary workers, and the way they used fixedterm contracts and TAWs, the permanent employees were the (cognitive) reference point against which such workers were compared. The fixed-term contract was in both countries described as the antithesis to a permanent contract, being not 'open-ended' and not providing employees an idea of a long-term relationship, as this manager in manufacturing in Norway expresses:

It is much more profitable for us to keep the skilled employees that we already have for longer periods of time. In that way we are able to give them proper training and they 
become independent. And then you, as an employee, will be interested in keeping your job. You learn something every day. You are allowed to develop. My opinion is that this is hard to do on a temporary contract. We use temporary employees when we are in a crisis, when we are vulnerable. When we don't see any possibilities of using our own employees.

The extra work hours of the part-time employees in care services and retail were across most cases also described as atypical, as anomalies, and unwanted. As one manager stated

I'm not happy that I have a staff status that means I can't cope if someone is away on education or is sick. I can't manage employees' vacation because then there are gaps. I would like to have more staff permanently, maybe 3-4 people more, and to have adjustable schedules that allow you to work with relocating staff and getting regular staff on bolidays. I.../ I mean this is the staff I have in my staff status, then I told you that we have extra workers for as many hours as approximately 7 full-time employees. It's well 10-15 people. They have on-call or day by day contracts.

Yet, in some industries, manufacturing in Sweden and most warehouse companies, the use of temporary workers was widespread and considered normalized. For example, several Norwegian warehouses had rather high levels of temporary workers even though the basic reason for the engagements was a steadily increasing demand for products and workers. Some of the warehouse employers in Norway and Sweden, and manufacturing employers in Sweden, deliberately hired a low number of permanent employees, securing flexibility by means of temporary workers. With some exceptions in manufacturing and the food industry in Norway, production was dependent on non-standard work arrangements filling essential roles throughout the working day. Some of the larger warehouses and manufacturing firms in Sweden who used a high share of TAWs had, as large customers, special deals with the agencies. This made the labor-cost difference between agency workers and fixed-term workers small, given the hiring transaction costs for the latter.

We (have) a pretty good price on the basis that we are quite a large customer /.../ We don't pay uniforms, health benefits /.../ for the TAW. I do not have the exact figures but it is actually quite a small difference in the long run. /.../ In a position where we have to lower our volume we will benefit from the TAW in half a day. (HR-person SF1)

The hourly cost of agency workers was still higher than using own employees, but according to managers in Swedish manufacturing, and warehouse firms in both countries, the saving pertaining to recruitment and overstaffing lowered the overall labor costs of using TAWs. Therefore, while there were strong norms regarding permanent contracts, there was a much weaker managerial understanding of when and how the use of non-standard employees was not just ad-hoc adjustments to cover for absent workers or temporary needs, but could be viewed as an implicit strategy where management relied on a limited core of permanent staff and where every kind of variability required atypical responses. As stated by one of the manufacturing managers in Sweden: 
We don't reduce the number of permanent employees and replace them with agency workers/.... It looks exactly the same as before, except that we have long-term sustainability in taking agency workers in. We don't need to alert the staff due to job shortage, to resign employees, move people around and hire staff back / / Maybe we have more permanent employees on jobs that require more skills, more time to learn, while you have short-terms where people usually are newly hired.

Sometimes non-standard labor was also preferred as a means to circumvent regulatory obligations pertaining to open-ended contracts. Several managers in manufacturing in Sweden, for example, partly used temporary workers to avoid, in times of recession, that redundant employees would have a right to regain their job if the company eventually would re-hire employees in the same position within a year. Such processes were described as time-consuming and slowing down adjustment. Even though similar rules apply in Norway, such considerations did not influence personnel strategies in the Norwegian manufacturing companies, although they had all downsized several times recently and anticipated dismissals also in the years to come.

Most of the companies in manufacturing, care services, and the food industry had local unions who, following the central agreement, must be informed about the use of temporary workers and why. These unions did, according to the employers, follow-up and express discontent if the employer used temporary workers in situations which were understood as illegitimate. In some instances, the Norwegian, not the Swedish, employers in these industries 'knew' - anticipated - that the shop steward would react negatively and therefore hired permanently instead. Thus, employer - union relations and more or less loose understandings or negotiated practices did influence the use of fixed-term contracts and TAWs in some cases. Further, some managers stressed that in a serious company as theirs, a 'proper' image of its employer-employee relations was important. It was especially important for companies reliant on attracting competent, qualified employees from small, local labor markets, and in manufacturing in Norway.

Although we found more or less the same type of practices and choices within similar workplaces in Norway and Sweden, the Swedish companies used a higher share of the different types of temporary workers. Despite stressing the importance of permanent contracts, the more liberal Swedish rules seem to imply that Swedish companies have a longer list of situations where they regard use of non-standard contracts as (cognitive) natural and normatively legitimate. As mentioned, the share of temporary workers due to strategic and systematic buffering was higher in the male-dominated Swedish industries, not only manufacturing and the food industry but also warehouses. Even though the cognitive and normative perceptions were rather similar, the regulative differences apparently lead to broader acceptance for and higher levels of temporary workers in male-dominated industries in Sweden than in Norway.

The interviews thus show that the impact of national regulatory differences was rather gendered. In contrast to the emphasis on swift and flexible adjustment of staff size in manufacturing, warehouse, and food industry in Sweden, the female-dominated care services and retail companies in both countries only used FTE occasionally and reactively to secure stability. Due to a given number of permanent contracts/positions in care services, provided by the municipality or owners, and the rules of the shift agreement, it was difficult to adjust the staff by way of permanent employees. 
When you set up the shifts and only have full time positions, it does not add up. /.../ If I only have ten man-years, it's impossible to reach this goal with just ten people. Often in the schedule, you have to divide the man-years on several people./.../ they [the trade unions] want everyone to have full time positions, but it does not add up.

Care managers further underlined that they could not hire (formally unqualified) assistants on permanent contracts. On-call workers and part-timers working more than stated in their contract were therefore strategically used as an ad-hoc solution. Despite being dependent on on-call workers, this group was not seen as part of the general staff, but as a necessary periphery, similar to the findings in Håkansson et al. (2013). Thus, there was a rather strongly gendered difference in justifications for and use of labor between companies in the male-dominated industries based on full-time workers, creating flexibility by way of temporary workers, and the female-dominated industries basing their flexibility mainly on the extra hours of part-time workers.

\section{Impact on recruitment and screening}

As shown, national employment regulations, norms, and (cognitive) perceptions influence employers hiring strategies. If employers use fixed-term and agency workers for screening purposes, how?

Only a few employers stated that they hired employees by way of agencies as a form of 'probation', securing that the employees had the qualifications needed. When asked about their use of temporary workers, one warehouse manager in Norway replied:

We have not really used much fixed-term employees in the company. The collaboration with the temporary work agencies works fine. And they are good at recruiting. That's what matters. It takes us a lot of time recruiting people. They often have a large database with lots of people that can do different tasks.

Hence, TAWs were considered to increase flexibility, and save time on screening and recruitment. This was highlighted by managers in manufacturing and food industry in Sweden and warehouses in both countries, especially related to jobs with low skill requirements and where it was demanding to select between job seekers on basis of their formal qualifications. This indicates that the opportunity to screen and select candidates for longer-term recruitment were for some a more or less unintended consequence of hiring through temporary agencies. Another implication of these findings is that easier access to temporary jobs in no way means that the employers become less attentive to skills or performance when ranking the queue of job-seekers. As the need for training in these types of jobs was limited, managers appreciated that they could immediately substitute TAWs performing poorly. If performing well and a long-term need occurred, employers offered in several cases a fixed-term contract sometimes leading to permanent hiring. Especially managers in warehouses stated that they rarely offered a fixed-term contract to someone who was not already hired as a TAW. By contrast, only SM1 deliberately used fixed-term contracts to screen new hires. As that employer stated 
We have a new collective agreement that allows us to have 18 months of fixed-term employment. Thus, no vacancy or probation but an appointment without any special reasons. 18 months' employment unconditionally. We would have used that if we were employing. It is about seeing if the person is the right one.

When SM1 was expanding the number of employees substantially, all workers were hired on a 1-year contract, even though the management knew they probably needed a large share of them permanently. Except for SM1, screening of those holding a temporary contract was not viewed as an intentional choice, but it occasionally happened as a reactive $a d-h o c$ consequence where companies insecure about their longer-term needs hired fixed-term or agency workers to reduce uncertainty. As with all employees, their job performance was evaluated, and they were screened if the employer eventually needed to hire someone permanently.

Even when having to fill temporary needs for labor with low and general skills, managers looked for the best qualified candidate and - in view of the short period of return on the hiring investment - preferred to avoid or minimize the costs involved in finding them. When recruiting full-time employees for unskilled positions - either permanently or temporarily - the retail and care service managers therefore said they reduce risk and costs by trying to select among the already prescreened staff of parttimers or on-call workers.

If there are any season employees who have proven themselves as being good at their job they might be offered the permanent position. The ad for the position are then just published internally and then they were encouraged to apply.

While managers in manufacturing and warehouses sometimes recruited by way of work agencies or fixed-term contracts, the labor market facing the potential employees on various positions mattered. When trying to get hold of workers in demand, such as truck drivers (costly driver certificate) or certified nurses, the managers were well aware - and convinced - that they had to offer a permanent position to get hold of someone qualified. Thus, perceptions, combined with the relative supply of labor and skills, working time preferences (differing among different groups, as well as by gender, in the labor market), and pure market power strongly influenced employers hiring decisions and their rationalizations regarding the choice of a permanent or fixed-term contract.

\section{Discussion and conclusion}

We have in this article studied 1) how and why employers use fixed-term contracts and TAWs; 2) whether and how differences between national labor market regulations and between industries affect employers' use of such workers; and 3) how the relationship between employers use of fixed-term employment, TAW, and work-hour flexibility varies between companies in different industries.

This study confirms statistics indicating that the regulatory differences between Norway and Sweden have a significant impact on employers' use of temporary workers, especially in manufacturing and the food industry. Further, the Swedish employers' 
higher use of temporary workers was apparently influenced by the stricter emphasis on tenure in dismissal regulation for permanent staff than in Norway. The Swedish manufacturing employers were clearly more concerned about the cost of potential downsizing processes and therefore more inclined to use TAWs than their Norwegian counterparts.

Our findings thus confirm with the theory suggesting that institutions - based on regulative, normative, and cognitive pillars - influence employers' motives, strategies, and choices. These institutional features are analytical dimensions: ideal types, which function in interaction with each other and other contingencies.

There were, despite regulative differences, strong commonalities within these laborintensive industries across the two countries regarding the motivations for using temporary workers. The main variations in the pattern for using temporary labor can thus to a large extent be explained by industry differences, lending support to the claim that industry-specific features are necessary complements to national industrial relations and regulations in accounting for variation in employer hiring practices.

In both countries, employers mainly used temporary workers as a last resort to increase numerical flexibility in provision of simple tasks and routine work, most pronouncedly in fulltime industries with predominantly male staff. They mainly choose temporary workers as a reactive $a d-b o c$ solution to fill gaps in the staff due to temporary demand increases, sick leaves, etc. Yet, employers in the male-dominated industries in Sweden did hire temporary workers more strategically, buffering a higher share of such workers in their companies. This all largely confirms with Atkinson's model of the flexible firm. While Holst et al. (2010) found the concept of ad-hoc adjustment helpful in explaining hiring of TAWs, our study indicates that this concept can be usefully extended to FTEs, which we find are used as a functional alternative to agency workers.

Our study makes very clear that employers' use of FTE is contingent on the alternative opportunities to meet temporary demand fluctuations or substitute for absent workers, for example, by way of TAWs or staff with on-call and part-time contracts. The availability of such alternative strategies varies across industries, depending on the pattern of production, work organization, and the gender profile of the workforce. Hence, our study shows that employers' use of FTE is significantly affected by industry-specific traits, rules for hiring TAWs, and the availability of other sources of labor/hour flexibility (see also Bechter et al. 2012; Svalund 2015).

Screening is often cited as a reason why employers hire temporary workers in quantitative studies, but there have been limited studies on how screening of temporary workers actually happen (Houseman 2001; Nesheim 2003). This study shows that managers seldom deliberately hire temporary workers to screen them, but that temporary workers were screened if and when managers needed to hire someone on a permanent contract. Our study thus reveals, not noticed before, that it is important to distinguish between hiring for screening purposes and the possible side effect that temporary workers already hired represent an important pool of recruits to be screened if needed. Further, types of temporary employment are sometimes combined in a stepwise hiring and screening process, first hiring individuals as TAWs, before screening and offering a fixedterm contract, and then sometimes being hired permanently.

Altogether, this study shows that employers do not judge temporary hiring as a simple, easy way around EPL for permanent employees. Throughout, the managers express a strong recognition of permanent employment as a norm, and that a permanent contract is the 'right' and 'best' way to organize the employee-employer relationship. The effect of 
this appears stronger in Norway, where stricter rules provide somewhat less leeway. The stricter rules were still interpreted quite loosely in several Norwegian companies, making the actual regulative difference between Sweden and Norway smaller in the mind of the managers. Still, the stricter rules in Norway were supported by stronger cognitive and normative sentiments about permanent contracts, as well as trade unions more actively sanctioning high shares of temporary workers (with the exception of warehouses).

Svalund and Berglund (2017), studying those holding a fixed-term contract 5 years later, find that the risk of marginalization is higher in Sweden. Studying hiring processes at company level, we find that with the more lenient regulation of fixed-term work and TAW in Sweden, the threshold and criteria for reactive ad-hoc use and more strategical hiring of temporary workers appear to be somewhat lower among the Swedish companies. Further, with higher shares of FTEs, it seems that Swedish employers are less inclined to eventually hire these workers on a permanent contract than their Norwegian counterparts. This indicates that although employers in the same industries in both countries display similar patterns of staff flexibilization aimed to handle variations in the need for labor, it seems that the higher Swedish incidence of temporary jobs flowing from the national differences in regulation of such work have made it harder for temporary workers to land a permanent job in Sweden, suggesting that tendencies toward segmentation or dualization between the labor market core and periphery are stronger in Sweden than in Norway.

\section{References}

Alsos, K. \& Evans, C. (forthcoming) Temporary work agencies: Triangular disorganization or multilevel regulation?, European Journal of Industrial Relations.

Atkinson, J. (1984) The flexible firm and the shape of jobs to come, Labour market issue 5, $1-19$.

Bechter, B., Brandl, B. \& Meardi, G. (2012) Sectors or countries? Typologies and levels of analysis in comparative industrial relations, European Journal of Industrial Relations 18: 185-202. doi: http://dx.doi.org/10.1177/0959680112452691.

Blanchard, O. \& Landier, A. (2002) The perverse effects of partial labour market reform: Fixed-term contracts in France, Economic Journal 112:, F214-F244. doi: http://dx.doi. org/10.1111/1468-0297.00047

Cho, J. \& Trent, A. (2006) Validity in qualitative research revisited, Qualitative Research 6: 319-340. doi: http://dx.doi.org/10.1177/1468794106065006.

Coe, N. M., Johns, J. \& Ward, K. (2009) Managed Flexibility, European Urban and Regional Studies 16: 65-85. doi: http://dx.doi.org/10.1177/0969776408098933

Davis-Blake, A. \& Uzzi, B. (1993) Determinants of Employment Externalization: A Study of Temporary Workers and Independent Contractors, Administrative Science Quarterly 38: 195-223. doi: http://dx.doi.org/10.2307/2393411.

DiMaggio, P. J. \& Powell, W. W. (1991) Introduction in: Powell, W. W. \& DiMaggio, P. J. (eds.), The new institutionalism in organizational analysis. Chicago: The University of Chicago press: $1-38$.

Doeringer, P. B. \& Piore, M. J. (1971) Internal labor markets and manpower analysis. Lexington, MA.: Heath Lexington Books.

Emmenegger, P., Häusermann, S., Palier, B. \& Seeleib-Kaiser, M. (2012) The age of dualization: the changing face of inequality in deindustrializing societies, Oxford: Oxford University Press. 
Eurostat. (2016a) Part-time employment as percentage of the total employment, by sex and age (\%) [lfsa_eppga]. Downloaded 15.01.2016, from Eurostat.

Eurostat. (2016b) Temporary employees as percentage of the total number of employees, by sex and age (\%) [lfsa_etpga]. Downloaded 15.01.2016, from Eurostat http://ec.europa.eu/ eurostat/web/lfs/data/database.

Gallie, D. (2007) Employment regimes and the quality of work, Oxford; New York: Oxford University Press.

George, A. L. \& Bennett, A. (2005) Case studies and theory development in the social sciences. Cambridge, MA.: MIT Press.

Håkansson, K. \& Isidorsson, T. (2007) Flexibility, stability and agency work: A comparison of the use of agency work in Sweden and the UK. In Furåker, B, Håkansson, K. \& Karlsson, J. C. (eds), Flexibility and stability in working life, Basingstoke, New York: Palgrave Macmillan: 123-147.

Håkansson, K. \& Isidorsson, T. (2012) Work Organizational Outcomes of the Use of Temporary Agency Workers, Organization studies 33: 487-505. doi: http://dx.doi.org/ $10.1177 / 0170840612443456$.

Håkansson, K. \& Isidorsson, T. (2016) Användningen av inhyrd arbetskraft i Sverige [The use of temporary agency workers in Sweden], Arbetsmarknad \& arbetsliv 22: 47-67.

Håkansson, K., Isidorsson, T. \& Kantelius, H. (2013) Stable flexibility. Strategic long term use of temporary agency workers in Sweden, International Journal of Action research 9: 278-300.

Holst, H., Nachtwey, O. \& Dörre, K. (2010) The strategic use of temporary agency work Functional change of a non-standard form of employment, International Journal of Action Research: 108-138. doi: http://dx.doi.org/10.1688/1861-9916 IJAR 201001 Holst.

Houseman, S. N. (2001) Why Employers Use Flexible Staffing Arrangements: Evidence from an Establishment Survey, Industrial and Labor Relations Review 55: 149-170. doi: http:// dx.doi.org/10.1177/001979390105500109.

Kalleberg, A. L., Reynolds, J. \& Marsden, P. V. (2003) Externalizing employment: flexible staffing arrangements in US organizations, Social Science Research 32: 525-552. doi: http://dx.doi.org/10.1016/S0049-089X(03)00013-9.

Korpi, T. \& Levin, H. (2001) Precarious Footing: Temporary Employment as a Stepping Stone out of Unemployment in Sweden, Work, Employment \& Society 15: 127-148. doi: http://dx.doi.org/10.1177/09500170122118805.

Lindvall, J. \& Rueda, D. (2014) The Insider-Outsider Dilemma, British Journal of Political Science 44: 460-475. doi: http://dx.doi.org/10.1017/S0007123412000804.

Mahoney, J. \& Thelen, K. (2010) A theory of gradual institutional change. In Mahoney, J. \& Thelen, K. (eds), Explaining Institutional Change: Ambiguity, Agency and Power, Cambridge: Cambridge University Press: $1-37$.

March, J. G. \& Olsen, J. P. (1984) The New Institutionalism: Organizational Factors in Political Life, The American Political Science Review 78: 734-749. doi: http://dx.doi. org/10.2307/1961840.

Marginson, P., Arrowsmith, J. \& Sisson, K. (2004). European integration and industrial relations: multi-level governance in the making. Basingstoke: Palgrave Macmillan.

Morikawa, M. (2010) Volatility, Nonstandard Employment, and Productivity: An empirical analysis using firm-level data, Research Institute of Economy, Trade and Industry (RIETI). Downloaded from http://EconPapers.repec.org/RePEc:eti:dpaper:10025.

Nergaard, K. (2016) Tilknytningsformer $i$ norsk arbeidsliv: Nullpunktsanalyse [Contract forms in norwegian work life: Baseline analysis]. Oslo: Fafo-rapport; 2016:07.

Nesheim, T. (2002) National Employment Regimes and Firms' Staffing Arrangements: Insights Gained from Comparing Norway as an 'Ideal Typical Case' with the United States 
and the United Kingdom, International Journal of Comparative Labour Law and Industrial Relations 18: 299-314.

Nesheim, T. (2003) Short-term hires and the leasing of personnel in Norwegian firms: promoting numerical flexibility and stability, Scandinavian Journal of Management 19: 309331. doi: http://dx.doi.org/10.1016/S0956-5221(03)00002-2.

Nesheim, T. (2004) 20 år med Atkinson-modellen: Åtte teser om 'den fleksible bedrift' [20 years with the Atkinson model: Eight theses about the "flexible firm"], Sosiologisk tidsskrift 12: 3-24.

OECD. (1994). Employment Outlook. Paris: OECD.

OECD. (2013). Employment Outlook 2013 Paris: OECD. doi: http://dx.doi.org/10.1787/ empl outlook-2013-en.

Olsen, K. M. \& Kalleberg, A. L. (2004) Non-Standard Work in Two Different Employment Regimes, Work, Employment \& Society 18: 321-348. doi: http://dx.doi. org/10.1177/09500172004042772.

Polavieja, J. G. (2003) Temporary Contracts and Labour Market Segmentation in Spain: An Employment-Rent Approach, European Sociological Review 19: 501-517.

Pollert, A. (1988) The 'Flexible Firm': Fixation or Fact?, Work, Employment \& Society 2: 281-316. doi: http://dx.doi.org/10.1177/0950017088002003002.

Ragin, C. C. (1987) The comparative method: moving beyond qualitative and quantitative strategies. Berkeley, Calif.: University of California Press.

Rueda, D. (2006) Social Democracy and Active Labour-Market Policies: Insiders, Outsiders and the Politics of Employment Promotion, British Journal of Political Science 36: 385-406. doi: http://dx.doi.org/10.1017/S0007123406000214.

Scott, W. R. (2003) Organizations: rational, natural, and open systems. Upper Saddle River, N. J.: Pearson Education International.

Scott, W. R. (2008) Institutions and organizations. Thousand Oaks, Calif.: Sage Publications.

Statistics Sweden. (2016) Befolkningens utbildning och sysselsättning 2014 - Educational attainment and employment of the population 2014. Stockholm: Statistics Sweden.

Svalund, J. (2015) Adjusting labour through crisis: A three industry comparison, Economic and Industrial Democracy 36: 99-121. doi: http://dx.doi.org/10.1177/0143831x13499619.

Svalund, J. \& Berglund, T. (2017) Fixed-term employment in Norway and Sweden: A pathway to labour market marginalization?, European Journal of Industrial Relations 0: 0959680117740777. doi: http://dx.doi.org/10.1177/0959680117740777.

Svalund, J., Casinowsky, G. B., Dølvik, J. E., Håkansson, K., Jarvensivu, A., Kervinen, H. mfl. (2013) Stress testing the Nordic models: Manufacturing labour adjustments during crisis, European Journal of Industrial Relations 19: 183-200. doi: http://dx.doi. org/10.1177/0959680113493838.

Uzzi, B. \& Barsness, Z. I. (1998) Contingent Employment in British Establishments: Organizational Determinants of the Use of Fixed-Term Hires and Part-Time Workers, Social Forces 76: 967-1005. doi: http://dx.doi.org/10.2307/3005700.

Vidal, M. \& Tigges, L. M. (2009) Temporary Employment and Strategic Staffing in the Manufacturing Sector, Industrial Relations: A Journal of Economy and Society 48: 55-72. doi: http://dx.doi.org/10.1111/j.1468-232X.2008.00545.x

Vosko, L. F. (2010) Managing the margins: gender, citizenship, and the international regulation of precarious employment, Oxford: Oxford University Press.

\section{Notes}

1 The term 'Temporary workers' is used throughout the article for fixed-term employees and temporary agency workers. 
2 The figures for regulations affecting fixed-term contract are based on OECD index code EPFTC (own calculations).

3 The figures for regulations affecting temporary agency work are based on the 2013 OECD index code EPTWA (own calculations).

4 Abbreviations are used when describing the case companies throughout the article. The first letter indicates country $(\mathrm{N}=$ Norway or $\mathrm{S}=$ Sweden $)$, the rest indicates the industry in which the company belongs: M (Manufacturing), CS (Care services), W (Warehouse), FI (Food Industry), R (Retail). 